\title{
The Hairdresser of Harare by Tendai Huchu: A hard-hitting etiological critique of the social and political malady bedeviling contemporary Zimbabwe
}

\author{
Mamadou Abdou Babou Ngom \\ Researcher in Anglophone African literature \\ Cheikh Anta Diop University, English Department \\ Dakar, Senegal (West Africa)
}

\begin{abstract}
This research paper sets out to delve into the root causes of the multifaceted woes bedeviling contemporary Zimbabwe through The Hairdresser of Harare by one of present-day Zimbabwe's most talented and celebrated novelist, Tendai Huchu. The article argues that decades of misrule and its attendant downsides of corrupt practices have brought the country pretty much to its knees. The grassroots fell hard done by as they are reduced to living by their wits in order to get by. Tendai Huch's lead character and narrator's repeated flashbacks to the promising beginnings of nationhood and her relentless delivery of strictures on the crass disregard for the law across the board bespeaks a sense of anticlimax over the betrayal of the ideals of the liberation war. The Hairdresser of Harare is a scathing indictment of a deeply failed leadership whose malign backwash effects percolate through every strata of society.
\end{abstract}

Key words: misrule corrupt practices homosexuality postcolonial

Tendai Huchu (1982-) is a Zimbabwean novelist and writer all into one. He pursued higher education at the University of Zimbabwe where he spent a short spell as a mining engineering student. Prior to the close of the first term he quit on unsubstantiated grounds, and became a binman although, by his own admission, he comes from a pretty much loaded background. Tendai Huchu is a by-word for courage and doggedness as well as purposefulness as he rose from a subservient job to reach prominence in writing. His debut novel, to wit The hairdresser of Harare, came out back in 2010 to international acclaim. Subsequently, he wrote The Maestro, The Magistrate and The Mathematician (2014) and An Untimely Love. His eclecticism in terms of fiction and nonfiction genre is a measure of his mould-breaking mindset.

Arguably, Tendai Huchu is a writer well steeped in the consciousness of his time. His nononsense call to fictionalize the multifaceted social cum political woes plaguing postindependence Zimbabwe bespeaks a strong belief in the values of art as an eye opener and a cost-effective vehicle of social change. Against a background of a country dogged by corruption, graft, bribery, lack of basic services, any writer worth his salt cannot fail to sit up and take notice. A writer's "private view"1 can only be of substance to the commonweal if he enjoys, as it

\footnotetext{
${ }^{1}$ In her seminal work, The Essential Gesture: Writing, Politics and Places, the late sophisticated South African writer Nadine Gordimer devotes an entire essay, to wit "A Writer's Freedom", on the role of the writer in society. From the get go, Gordimer spells out her understanding of a writer's freedom by contending that "it is his right to maintain and publish to the world a deep, intense, private view of the situation in which he finds his society." She goes on to emphasize that the writer's success in his lofty calling entails an adamant refusal of partisanship. To put it differently, "freedom from the public conformity of political interpretation, morals and tastes" must be granted to him as a stepping-stone to better serve his society across the broad. A writer's moral compass should shepherd
} 
were, a foolproof bulwark against unsavoury pressure from both sides of the political divide. Tendai Huchu is immune to the bane of political pressure and strictures of literary censorship as he writes from exile. The cocoon of his exile in Edinburg affords him the possibility of delivering a hard-hitting sobering critique of the unaddressed social issues and misrule besetting his country with the express aim to jolt his fellow citizens and the international community alike into consciousness about the necessity to stop the rot. The situation of modern-day the erstwhile-British colony is baffling and disgusting no end. According to leading Zimbabwean academics, the fact that the postliberation leadership paid lip service to the necessity for a genuine political reconciliation across the racial divide:

In the 24 years since independence Zimbabwe has moved from being perceived as a model of racial reconciliation in a post-guerrilla-war context to receiving widespread condemnation as a result of the ruling party's repudiation of this reconciliatory politics. (Raftopoulos and Savage viii)

Indeed, there was a hugely yawning gap of mistrust and dislike between winners and losers after the liberation war ended with The Lancaster House agreement of 1979. White Zimbabweans feared that the new black ruling class might embark upon a vengeful policy against them. However, Robert Mugabe, in a politically calculated move, sought to assuage their misgivings and anxiety:

It could never be a correct justification that because the Whites oppressed us yesterday when they had power, the Blacks must oppress them because they have power. An evil remains an evil whether practiced by white against black or by black against white. Our majority rule would easily turn into inhumane rule if we oppressed, persecuted or harassed those who do not look or think like the majority rule. (qtd. In Raftopoulos and Savage xi-ii)

This placatory narrative about the necessity for fence mending between the warring sides amounted to no more than sheer window dressing. Mugabe's post-independence leadership style flew in the face of the dispositions of The Lancaster House agreement, not the least of which was "a series of compromises over minority rights, in particular on the future of land ownership in the country, and guaranteed white representation in parliament" (Raftopoulos and Mlambo). Much as he intently drew on the obnoxious legacy of colonialism to fuel his anti-West sentiment and viewed any democratic openness as the thin end of the wedge, the fact remains that the first two decades of his leadership bears commending. When Zimbabwe achieved statehood, its education system still bore the hallmarks of a nefarious racist ideology whose suspecting end game was to keep the African population in a perpetual state of bondage. Mugabe's merit lay in the bold steps that he took with a view to redressing the inequalities and discrepancies pertaining to access to education:

When Zimbabwe gained independence from colonial rule in April 1980, the majority of the population did not have the opportunities and facilities for equal access to formal education. The education system was very restrictive for the Black population and most finished only six or seven years of primary schooling. (. . .) Over the first twenty years of independence, Zimbabwe witnessed incredible strides in school expansion, teacher training and resource improvement. (...) Primal schooling was made tuition free, and this resulted in gross admission rates that exceeded $100 \%$. By the end of the

\footnotetext{
him towards the penning of what he deep down regards as truth for the benefit of the commonweal: "All that the writer can do, as a writer, is to go on writing the truth as he sees it. That is what I mean by his 'private view' of events, whether they be the great public ones of wars and revolutions, or the individual and intimate ones of daily, personal life." Yet she bemoans the fact that during apartheid-era South Africa writers of conscience did not enjoy the possibility to write their "private view" of the situation as they were hamstrung by fear and anger. PP.104-5.
} 
first decade of independence, Zimbabwe had achieved universal primary education. (Shizha and Kariwo xi)

Things started going awry when President Mugabe embarked upon a swingeing land redistribution drive through the trope of righting the wrongs of one of the multifaceted hangover laws from colonialism. While some lauded the land reform move as a huge step towards healing the psychological and physical wounds spawned by oppressive colonial land laws, others saw in it a ploy designed to staunch the plummeting popularity ratings of the longtime ruler. At any rate, the land reform blueprint triggered a huge political and economic crisis that came to a head with the president's resignation on 21 November 2017 after 37 years of iron fist rule. The Mugabe years has given rise to no end of non-prose and prose fiction, not the least of which is Tendai Huchu's The Hairdresser of Harare.

A breakout novel shot through with social and political commentary, The Hairdresser of Harare came out in 2010. It is once a riveting and easy read. It recounts a story from the point of view of Sisi Vimbai, a single mother in her mid-twenties raising a child born out of wedlock, and selfstyled best hairdresser of Harare. She earns her livelihood in the "Khamalo Hair and Beauty Treatment Salon", which is situated "in the Avenues, a short walking distance from the city centre" (Tendai 1). The salon is the favorite hangout of a good many loaded Harare denizens reportedly thanks to Vimbai's proven credentials as a crack hairdresser. Quite unexpectedly, an event happens which utterly upsets the applecart of Vimbai's leading position in the salonthe arrival of a new hire. As it happens, a twenty-two-year-old man who has an afro and "with a well-proportioned boyish physique", gone by the name of Dumisani Ncube, walks into the salon, asking to fill in a vacancy. Not surprisingly, Mrs Khumalo (the supremo of the salon) is taken aback. Her astonishment stems from the realization that in modern-day Zimbabwe men think nothing of taking up jobs naturally earmarked for women. In a move calculated to get shot of the young man, Mrs Khamalo, says, "Young man, d'you think I am looking for a garden-boy? I want a hairdresser." The young boy's comeback is every bit as astounding as challenging: "I can do the job Mrs Khumalo, if you give me the chance" (7). In an endeavour to display his mettle he somewhat unruffled the hair of the woman who has just been styled, saying, "Your hair was set beautifully, but the style she's given you is not for you." On top of that, "You have a round face, so instead of these curls we need to layer it so that it flows with the smooth contours of your face" (7). Just like that he "worked briskly with his comb, then took a pair of scissors to trim the ends" under the bemused gaze of the whole salon. When he is done, he makes Matilda look in the mirror and then asks her for her opinion. "I look like Naomi Campbell," she replies. As she is about to jot down Dumisani's details in the event of her needing him later on, Mrs Khumalo steps in and ushers her to the door, with a cast-iron promise: "Don't worry, you'll find him next time you come" (8). Mrs Khumalo goes on to take the young man's particulars and straightaway "told him that he was to start work the following Monday" (8). A fortnight into the job Dumi , as his workmates affectionately call him, somewhat leapfrogs Vimbai as the new star of the salon. Vimbai plumbs the depth of excruciating humiliation when Dumi gets promoted as manager over her despite having a longer history of service at the salons than him. Little wonder that she feels hard done by, and cannot help but bear a grudge against Dumi for her woes. However, Dumi is a most poised and considerate dude, so that he goes to great lengths to ensure that Vimbai does not feel belittled. As if to reward him for his attentions, Vimbai accepts to let Dumi a room in the house that she inherited from her late brother Robert, thereby becoming her workmate's landlady. As time wears by, the co-tenants get more intimate. Nonetheless, she vows to not make it in bed with Dumi should he express that wish, for the psychological and physical scars spawned by her daughter's father's betrayal still rankle. By a strange quirk of fate, Vimbai gets to know Dumi's parents and relatives who look on her as their daughter-inlaw. There is more to Vimbai and Dumi's relationship than meets the eye. Both have different 
futures in mind. When Vimbai arrives home from work one day, she is astonished to find Dumi and a high-profile minister's husband locked in his room. This plants seeds of suspicion in her mind. If anything, she profits from Dumi's temporary absence to search high and low in his room until she happens on his diary. What she discovers shatters her no end: Dumi is, lo and behold, gay. She finds herself in a double bind. On the one hand, she cannot bring herself to continue her relationship with Dumi because of her strong animus against the immorality of homosexuality. On the other hand, the idea of returning good for evil vis-à-vis Dumi's parents pricks her conscience.

The Hairdresser of Harare is, to all intents and purposes, a novel of his time. It is set against a backdrop of harsh economic and social as well as political travails in Zimbabwe. The turmoil facing this Southern African country in the aftermath of a piecemeal land reform blueprint has left denizens of Zimbabwe, not the least of which those of the capital city -Harare- trapped in a daily quest for survival strategies. Oftentimes, survival game plans fly in the face of the rule law. Witness the mess that reigns supreme in the transportation system. Not only cars and buses are not roadworthy to the say the least, but, more importantly, overcrowding is a daily treacherous occurrence despite being a disaster waiting to happen with unintended consequences. The woes plaguing the transportation system are compounded by a shamefully gross paucity of cars the unroadworthiness of which is unchallengeable, "taking a Kombi is always a daunting task. The first problem is getting on one, especially from Samora Machel where I took," (23) explains Vimbai. As a result, private and public sector workers are hard put to it to arrive at work in time. The appalling oddity of the transportation system brings about eyewatering fare increases. It can be also be rightly argued that the shortage of petrol factors into the occurrence of the bottle neck of urban mobility in Harare, thereby ramping up the stress and strains of commuters and civil servants alike. The female narrator's sense of despondency about the dereliction of the transportation service in her country is writ large:

There a lot of kombis but they seemed to spend most of their time quieting for petrol that, when it could be found - and stalled when they had it. The few petrol stations that had fuel accepted foreign currency or coupons though it was still technically illegal to carry out transaction in foreign currency. (22-3)

The dearth of petrol and its attendant rationing means that people feel compelled to resort to shady practices to scrape by. This is testament to Zimbabweans' resourcefulness in the face of overwhelming odds:

There was a sizeable group of us waiting as cars trickled past on the carriageway. It was rush hour but they moved ever so slowly in an attempt to save fuel. I tried hard not to think about the brief period in my life when I moved about in a car. Some drivers stopped to pick up people. We called it piracy and it was illegal. (24)

Overcrowding in cars and buses is an eyesore in addition to being a reproach to society; it carries the seeds of misrule and crass disregard for the rule of law, which can be a recipe for anarchy. Heavy-duty means of transport are supposed to smooth mobility; but in a society markedly characterized by a yawning gap between haves and have-nots, those who are left to their own devices are prone to throw caution to the winds to make something of themselves. In the world of The Hairdresser of Harare denizens at the bottom of the social pecking order fall back on mean expedients to get by. A perfunctory description of the atmosphere in a kombie coupled with the dereliction of duty attendant upon the management of bus services is a measure of the degree to which destitution and unabashed disregard for the law born out of decades of misrule have eaten into the fabric of Zimbabwean society:

(...) I was sandwiched between other bodies and could hardly breathe. The seat designed for three was filled with four people with the hwindi [italicized in the novel; 
so, it is I who underline] leaning over our laps because there was no space for him. Crowding to maximize profits. The smell of sweat and bad breath was overpowering. Even after a lifetime of experience, it was impossible to enjoy this kind of travel. I can vaguely recall a time when we had buses to a timetable in Harare. The kombie had no timetable and observed so few rules that you had to pray you'd reach your destination because quite often they'd just decide to change their route and leaving you stranded. (24)

Tendai Huch paints a gritty picture of the dysphoric malaise that has brought about a free-forall with people playing hardball tactics to get their own way. Every strenuous human agency is geared towards a goal of survival. The notion of adaptation which Heinz Hartmann describes as being "the capacity to cope appropriately and advantageously with one's environment" (qtd. In Salman Akhtar 4) stands out in bold relief in the daily grind of earning one's keep. Interestingly, those whose moral compass is anchored in the deep-dyed values of honesty and dignity seek to pull themselves up by their own bootstraps. As the narrator explains,

There were vendors selling freezits, maputi, maize cobs, fruit, eggs, and vegetables. It seemed as though there were more vendors than purchasers. With no jobs available everyone tried to sell something just to eke out a living. Almost every second house had a wooden shack near the gate: tuck shops, only a little classier than the vendors with their makeshift stalls. (25)

Indeed, this bunch of toilers embrace what Heinz Hartmann calls "autoplastic" adaptation which plays out when "the individual modifies himself in response to the environment" (qtd. In Salman Akhtar 4). To put it differently, they make virtue out of necessity. They fend for themselves, and try to keep on the straight and narrow as opposed to stooping so low as to look to theft and shady practices to make ends meet. The measliness of their daily proceeds may be a disincentive but, when you think about it, it is cold comfort in that street hawkers can take heart from a sense of self-fulfillment stemming from the fact of their means of livelihood being aboveboard. On the other hand, the pervasiveness of the scarcity of jobs and the uptick in fatalities from the backwash effects of food shortages and an astoundingly crippling health system have given rise to a bunch of rogues who live by their wits; they are ensnared in a life of unconscionable crime that does not leave the dead at rest. Actually, when folks inter a loved one they provide against defilement in any shape or form by 'grave robbers'. Their strategy consists in denting parts of the coffin to make it useless for would-be offenders. Vimbai teeters on the brink of tears when she visits the cemetery to pay respects to her late brother Robert because of its unkempt state (58). To boot, instances are thick on the ground of graves without tombstones, "A few of the graves were covered in concrete. Fewer had tombstones on them. The vast majority looked-like sweet potato mounds of earth with sticks on top to resemble across" (28). The desperate meanness of the steps taken to shield the dead against nefarious aggression bespeaks a society that borders on anarchy:

I laid flowers on the grave [that of Robert], then remembered I had to break the stalks otherwise they would just be stolen and re-sold. Grave robbers worked shifts here too. A funeral had been turned into an exercise to prevent theft. On the day of the burial, before we had lowered him down, men stepped forward to bash the coffin and scar so it would be of any value for anyone who might be thinking of digging it up and selling it. Despite that there was a risk his suit would be stolen. It was a hopeless battle, as the cemetery had no guards. (29)

Cemeteries are a place of remembrance of huge psychological and historical purport. They link the dead to their loves ones who are still alive; their defilement be it for robbery or sacrificial means constitutes a most nefarious criminal offence. The sacredness of a resting place lies in 
the fact that it stands as a material monument to the achievement of closure without which mourning arguably never ends. French sophisticated historian Pierre Nora reckons cemeteries amongst what he calls les lieux de mémoire or "memory sites". Nora defines a lieu de mémoire as "any significant entity whether material or nonmaterial in nature, which by dint of human will or the work of time become a symbolic element of the memorial heritage of a community" (Nora XVII). In Nora's estimation, a site, an object or an event qualifies as memory only when it carries an aura of symbolism and when "there is a will to remember." Of note is the contention that memory gears itself to the here and now and locates itself in places, which puts people in mind of a lived experience traumatic or otherwise. He elaborates upon the dividing line between memory and history as follows:

Memory is always a phenomenon of the present, a bond tying us to the eternal present; history is a representation of the past. Memory, being a phenomenon of emotion and magic, accommodates only those facts that suit it. It thrives on vague, telescoping reminiscences, on hazy general impressions or specific symbolic details. (...) Memory situates remembrance in a sacred context. (Nora 3)

The holiness encapsulated in a memory site, i.e., a cemetery, is a significant push factor for its reverence and worship. As David L. Carmichael writes,

A sacred site is a place which is considered holy, is partially or wholly reserved for magico-religious or ceremonious functions. Because of this it is venerated and revered and is kept free from contamination by sin or evil (...) They are usually characterized by the presence of artefacts and features that are unique to them. (Carmichael et al. 132)

Tombstones reckon amongst those features and artefacts that are the hallmarks of such a memorial site as a burial ground. Vimbai's beef about the lack of tombstones on the graves is not a perfunctory complaint by any stretch of the imagination. There is more to a tombstone than meets the eye. A tombstone may go unnoticed to the passer-by, yet, beyond its function of guidance, it acts as a fillip to the wholesome duty of remembrance as opposed to thorough forgetting:

What is written on the unperishing (sic) tombstone is a mute message of the dead to whoever is alive - a symbol of a perhaps still unarticulated feeling that the only way in which a dead person lives on in the memory of the living. (Elias 33)

In The hairdresser of Harare, intractably trying times feed into a general sense of socio-political malaise that is so deep-seated as to completely blind people to what is supposed be fall within the realm of ethical responsibility. The uncalled-for absence of guards for the burial site adds to the crassly pervasive dysphoria.

Grassroots Zimbabweans are bearing the full brunt of the disastrous fallout from agricultural and economic policies made on the hoof, yet they are possessed with a stunning sense of bouncebackability, which makes them tick:

It surprised me with only ten per cent of the population employed, the streets were full people bumping past each other first thing in the morning. I passes a vendor whose business consisted of selling single mints and single sticks of cigarette as I turned into Robert Mugabe Road. (50-1)

Their adamant refusal to let the multifaceted maladies gripping their country get them down is a measure of a stunning resiliency. Even though some prefer the line of the least resistance by deviating from the straight and narrow to get involved in theft and other abhorrent malpractices, the bulk of the population eke out a living decently. Stuff like "maize meal, sugar, 
salt and cooking oil" are bread and butter issues that "always one had to be on the look out for" (50). In a move meant to keep starvation at bay and see their offspring through their schooling years, the likes of Vimbai stint themselves:

The next morning I left home early making sure that Maidei warmed some water for Chiwoniso's bath. I had had to switch off the geyser to save on electricity. It would have to be that until things improved. I got a lift from a man who was pirating and he dropped me off at the main post. It took me time to cross the street because the traffic light was not working and no one wanted to give way. (50)

It is worth noting that Meidei and Chiwoniso are part of Vimbai's household- the former being her charlady and the latter her daughter. Thanks to the "maintenance order" that she gets from Philip Mabayo (Chiwoniso's father) Vimbai manages to keep body and soul together. The envelopes of money helped defray the expenditure respecting Chiwoniso's "school, clothing, food, medicine" but the payments stopped all of a sudden following a spat with her daughter's obnoxious father (41). The erratic supply of electricity; the paucity of running water; skyrocketing unemployment rates; inflationary spikes; battered roads and old-school buses: this morass makes a mockery of the average Zimbabwean's gritty everyday drive to scrape by. What deserves again elaborating upon is people's resilience and pluck as well as determination to eschew wallowing in a pitying narrative about their predicament:

Almost every second house had a wooden shack near the gate: tuck shops, only a little classier than the vendors with their makeshift stalls. Within each was a family member, no doubt a minor, looking bored, and waiting for the very occasional customers to dribble in. (25)

Ironically, amidst the mayhem what stands the wear and tear of time are vestiges from a bygone era, not the least of which is the City Council headquarters whose quality of architectural grandeur acts as a foil to dilapidated post-liberation struggle buildings, and to the human ravages attendant upon bad governance:

The old building stood in its glory as if the colonial times were mocking the failure of our independent era. It was still the city City Council headquarters. The colourful Zimbabwean flag drooped impotently in the smog-filled stagnant atmosphere" (50).

Of note also is the white elephant status of a colonial leftover crucial to the country by its historical purport:

There was a curious feature in the square in front of the building. It was a silverish metallic ball with spikes that looked like a hastily cobbled piece of modern art by a $D$ grade O-level student. It was the fountain, from which not a drop of water ran. If my memory serves me right, it cost nearly a million when it was built, quite a fortune then, though it wouldn't buy a loaf of bread now. When it worked it produced a curious ball of water that was outstandingly unspectacular. It was quick to break down, just months after it was unveiled. Everything about the city council was broken except the official Mercs that made their way in and out of the gates, as if any real important business was taking place within. (50)

It looks as though the country were stuck in a time warp. The hint of wistfulness that colours the description of the inception of the aforementioned building is a sobering reminder of the failure of the lofty ideals that underpinned the liberation war, which took a most heavy human toll on countless Zimbabweans of African stock. Plainly, shades of Frantz Fanon's thinking shine through the foregoing quotation. Pretty much six decades ago, he warned that the understandable euphoria surrounding the wind of decolonization sweeping across the black continent might wind up being an anticlimax. His hard-hitting premonition stemmed from a 
blow-by-blow examination of the "deeply cosmopolitan mentality" (Fanon 98) of the national bourgeoisie, the latter referring to the crop of Western-educated Africans who rose to power out of the ashes of the colonial régime. Fanon's key premise was that there was no way for the national bourgeoisie to pull Africa from an economic cum cultural backwater unless they operated an utter mindset shift:

To our thinking (...) the historical vocation of an authentic national bourgeoisie in an underdeveloped country is to repudiate its status as bourgeois and an instrument of capital and to become entirely subservient to the revolutionary capital which the people represent. (99)

His strictures on the unpreparedness of the national bourgeoisie, which - "has lulled itself into thinking that it can supplant the metropolitan bourgeoisie to its own advantage" (98)-, have been vindicated by the leadership of postcolonial Africa, who espoused unabashedly the antics and showboating of those into whose shoes they stepped at the end of colonization. Fanon lambasts postliberation African leadership for their proclivity to feather their nest to the detriment of the masses:

This bourgeoisie especially in the aftermath of independence, has no scruples depositing in foreign banks the profits it has made from the national resources. Major sums, however, are invested for the sake of prestige in cars, villas, and all those ostentatious goods described by economists as typical of an undeveloped bourgeoisie. (102-3)

In light of the foregoing, Vimbai's lamentation that "Everything about the city council was broken except the official Mercs (...)" is a telling hint. Vimbai's recognition, talking to Lucy Price, that "Times are hard my sister" is evidence that Zimbabwean people are hurting, and that there is a great likelihood that they will not quail before any scam to make both ends meet. Lucy is both a regular and a supplier to the happening Khumalo Hair and Beauty Treatment Salon. When she puts Vimbai wise to a free delivery of sugar at Abbas and Sons "a largish Indian store, one of several in the down-town area" where a brother of hers works, Vimbai cannot wait to go there. Upon arriving, she finds that "There was a queue of about sixty people already there" (51). Just then, "A hand grabbed [her] from behind. [She] quickly turned clutching [her] handbag" (51). It turned out to be Lucy. They shook in their shoes while they "stepped past piles of rubbish and avoided puddles of brown water as [they] went up the back street", waiting for a sidekick with bated breath: "Lucy kept looking around worried that someone might follow us" (51). What is meant as charity is nothing less than theft writ large in disguise:

(...) The door opened suddenly and scrawny man with a shiny face stepped out. "Chop-chop," he said thrusting a bag at her and taking the money in one swift motion. My heart pounded as if I was taking part in a drug deal. As soon as he was done the man went back and shut the door. That was it. We had our sugar. Lucy gave me twokilogram packets of white and one two-kilogram packet of brown and we parted ways. She had just earned herself a free session the next time she came into the salon. (51)

Indeed, Vimbai's well-meaning call to volunteer "to meet up with Lucy" has paid off. The opportunity of coming by basic commodities through the backdoor is not to be missed out on, the more so since "you could get them at the gazette price and sell them on the black market for a quick profit" (50).

The anticlimactic twist that postliberation Zimbabwe has taken shines through inter alia the dyadic scourge of corruption and haphazard economic policies whose hallmark is a piecemeal land reform scheme. This unflattering picture of postcolonial Zimbabwe is broached in The Hairdresser of Harare. Postcolonial Zimbabwe is portrayed as a country where bribery, 
corruption and graft as well as the violent crack-down on dissent, have caused its people to live in reduced circumstances. The feeling of hopelessness is pervasive. Every strata of society feels the pinch of rampant joblessness. Nowhere is the said feeling more excruciating that in the field of education. In Vimbai's estimation, indeed, education in present-day Zimbabwe is all but a dead end, for the end game of striving to get an education is made a mockery of by the bleak future that lies ahead. As she prepares "to be away from the salon for a while" with Dumi, Vimbai sees pupils on their way to school from her house's vantage point. She cannot help but movingly ponder over the plight that is in store for them: "I stood at the gate and looked at the long procession of Churchill boys and Roosevelt girls going to school. Was there a future for them when they finished, I wondered?" (113). Casting her mind back, she is bitchy about how far post independence Zimbabwean leadership has failed her generation and that prior to hers:

The generations who came before us had stolen hope to such an extent that we regarded the future with trepidation. I knew people who never looked beyond the next day. Their circumstances only allowed them to focus on the here and now, which is pretty much what animals did, though we regarded ourselves as superior. (113)

Vimbai rightfully bemoans the preposterousness of life in her country. A life taken up with devising everyday survival strategies boils down to a bestial limitation to the present. The general whiff of malaise compounded by downbeat prospects for the future is undeniably writ large. Everyone has more than their fair share of living-related travails, as Vimbai appositely points out:

A lot of people greeted me as I walked along. I felt an atmosphere of friendliness, violence, innovation, poverty, joy but the one thing that hung everything else was despair; an air of hopelessness as if everyone was in a pit that they could not climb out of. I knew that feeling all too well. It's like seeing a plane high up in the sky and knowing that you will never be on it. (26)

Despair raises its ugly heard where hope ought to be. It is a measure of the erosion of the possibility of self-actualization. Little wonder that Søren Kierkegaard writes that "it is not only the greatest and misfortunate to despair" (11). The disgrace born from the predicament of being in despair makes a mockery of the despairing subject's raison d'être. When one despairs, one no longer dreams and, accordingly, the future represents a utopian universe in his scheme of things. Despair epitomizes a kind of rejection of the meaning of life, for "the despairing self is building nothing but castles in the air, it fights only in the air" (Kierkegaard 363); whereas hope is a fillip to agency. Despair, unlike hope which "includes a certain certitude with respect to the actualization of the hoped-for good" (Schumacher 66), somewhat dis-incentivizes the subject. From a Schopenhauerian philosophical standpoint, hopelessness turns into an unnatural condition as it grips the subject:

He who has given up hope has also given up fear; this is the meaning of the expression desperate. It is natural for a man to have faith in what he wishes, and to have faith in it because he wishes it. If this peculiarity of his nature, which is both beneficial and comforting, is eradicated by repeated hard blows of fate, and he is brought to a converse condition, when he believes that something must happen because he does not wish it, and what he wishes can never happen just because he wishes it; this is, in reality, the state that has been called desperation. (Qtd. in Schulz 47)

French twentieth-century renowned thinker Albert Camus is in lockstep with Schopenhauer when he says, "A man devoid of hope and conscious of being so ceases to belong to the future" (22). The absence of fear that goes with the territory of despair can be the start of the slippery slope towards suicide. Despair is never born in a vacuum. 
Another core strength of The Hairdresser of Harare in terms of thematic wellspring is its scathing indictment of the push factors for bad governance: corrupt practices. The astounding reach of graft together with other multifaceted nefarious deeds with its attendant economic and social downsides deserves swift remedial agency as it wreaks devastating havoc right through every strata of the society. One cannot emphasize enough that any corrupt system is nothing short of a huge setback to advancement. That is what Zimbabweans learn hard the way. In The Hairdresser of Harare corruption is so ingrained that it has become a social norm, so that a service that citizens from all walks of life are entitled to by right is turned into, as it sere, a scam for monetary self-serving ends. Witness what happens at the passport office. When Vimbai and Dumi's sister, Michelle, arrive at the passport office, they are stunned in no small measure by the length of the queue that "stretched right round the Registrar's office and onto the street" (122). Another shocker to Vimbai stems from the fact that "All the people waiting in line seemed to be young" (122). This, in her books, is extremely baffling, the more so since Zimbabwean youths were never so anxious to shake the dust of their country off their feet even. Even the gory war of liberation against the British did not cause so many people to leave the country $(\mathrm{HH}, 122)$. Hence the appositeness of her question: "Could it be that independence had become a greater burden than the yoke of colonial oppression?" (122). It is a sign of the times that kids of school age who have fallen by the wayside struggle to scrape by in the most laughable, demeaning of ways:

Street kids stood in the queue as well. They were an enterprising lot, selling their places towards the front and then promptly rejoining the queue at the back and waiting for the next impatient soul to buy their place. (122)

Vimbai and Michelle do not buy a good spot in line from the kids. Rather, they look for a quicker means to access the offices and comply with the formalities of a passport acquisition. Within half an hour of waiting, a fixer comes to meet them, and takes them to a room that has known better days. The dusty unkempt files elicits this remark from Vimbai: "It was clear that productive work seldom took place at the table" (123). If anything, the room is somewhat earmarked for shenanigans in the form of backscratching. A few snatches of Michelle's conversation with the fixer lay bare the depth of bribery in the country:

"What can I do for you, mainini (italicized in the novel; so, it is I who underline) Michelle? (...)

"My muroora (italicized in the novel) here needs to get a passport asap."

"These things are more difficult now than they used to be. There are more people to feed in local chain."

"Will this be enough?" She two bricklike wads of money on the table and slid them to him. He swiftly grabbed them and put them in a drawer under his desk.

"Stay here. I'll be right back." (123)

Unsurprisingly, the man returns half an hour later with a form for Vimbai to fill out. He goes on to take her fingerprints, whereupon he promises to deliver the much-needed passport in the span of a month. Meantime, Vimbai undergoes pricks of conscience. As she goes back home, noticing that the "queue had barely moved because people like [them] had kept jumping to the front" (123). Instances like this are, sad to say, thick on the ground in the picture of Zimbabwe painted by Tendai Huchu. Corruption is so ingrained in the psyche of Zimbabweans that it makes them tick. People live off kickbacks. This permissive matrix accounts for the erosion of road sense (not the least of which is the unconscionable disregard for the Highway Code) and for a pattern of asocial behavior that borders on anarchy. Against a backdrop of trying times, police officers think nothing of robbing drivers blind as a way to supplement their income, thereby flouting the potentially devastating fallout from allowing cars to circulate whose roadworthiness is a sham. The short shrift that professional and ethical etiquette get from law- 
enforcement agents play out through many scenes in the narrative. One that stands out is when Vimbai and Dumi board a kombi to make their way to Patrick's wedding, a senior brother of Dumi's. All of a sudden, the driver jammed on the brakes as they neared a roadblock. Just then, "Three policemen waved the cars in front of us through but stopped out kombi and told the driver to park near the pavement" (84). After checking the vehicle through and through, the police comes up with a hard-hitting assessment:

This commuter omnibus is unroadworthy (sic). The tyres have no treads, in fact, they are bald; there are no reflectors on your mudguard, and your wipers have no blades on them. This car is a death trap. I am sure if we take it down to the VID, they will find more problems. I have no choice but to impound it. (84)

Spot-on though this diagnostic appraisal is, an intention to up the ante lurks beneath the surface. Despite the driver's entreaties, "This car is my livelihood. If you take it away my family will starve", the cop sticks to his guns. He even seeks to claim the moral high ground over the driver as he backs up his hardline stance with a watertight reasoning:

I feel sorry for you, but I just have no choice. Public safety is not something we can toy around with. Just last week a kombi overturned on the Harare-Masvingo road because the brake pads were worn out and the driver could not stop in time. Ask your passengers to step out of the vehicle. (84)

All this discursive overkill is sheer window dressing. Against all expectations, the police officer driver offers to meet the driver halfway in brazen manner:

"Help me to help you," the officer said in the quietest of voices.

That was all the prompting the driver needed. He knew what to do. He took a large wad of banknotes and handed it to the policeman who pocketed it in a slow casual movement. (84)

The deal thus done, the cop waves the driver through but not without delivering a caveat that, to all intents and purposes, rings hollow because it is meant to salve his conscience, "I ' $m$ only doing this as an act of kindness; you have to get the problems on your car fixed. Next time, be quick to produce the right paperwork" (84). If you think about it, the practice of bribery, whatever the guise it comes under, carries undertones of human meanness. The agents involved in this nefarious business forfeit their dignity, register thereof their disregard for order that is crucial to a just society. John Rawls' conception of a well-ordered society reads as follows:

a society is well-ordered when it is not only designed to advance the good of its members but when it is also effectively regulated by a public conception of justice. That is, it is a society in which (1) everyone accepts and knows that the others accept and knows the same principles of justice, and (2) the basic social institutions generally satisfy and are generally known to satisfy these principles. (4)

A corrupt system forefends the mediation of a well-ordered society owing to the excessive selfishness as well as the unsavoury lust for easy money that betrays itself in it. All this goes to show that the brazen acceptance of the trinity of corruption, bribery and graft as a social norm encapsulates the rejection of honest toil as a gateway to self-actualization. Indeed, people who live by their wits show themselves to be the lowest of the low for whom social cooperation, which "makes possible a better life for all than any would have if each were to live solely by his own efforts" (Rawls 4), is a figment of the imagination. The practice of corruption is selfdefeating besides having a preposterous edge to as it weakens no end the bedrock of social cooperation without which "the modern man could not achieve the barest fraction of the ends and satisfactions that he has achieved with it. The very subsistence of the immense majority of us 
depends upon it" (Hazlitt 37). In a society bitten out of recognition by the rat race bug like that portrayed in The Hairdresser of Harare, where the Westgate Shopping Centre "made it feel like a first-world Mediterranean country" thanks to "its immaculate pinkish walls and the litter-free pavements" as well as "its plenty of customers with heaving shopping bags", corruption is bound to reign supreme. People whose conscience does not prick at the idea of accepting bribes have an eye for the top rung of the social ladder. The driving necessity for relentlessly fostering public awareness about corruption as part of the fight against it should come front and center for the benefit of society.

The gay theme of the novel bears testimony as it serves to highlight the plight of same-sex partners in Zimbabwe. The appalling discovery of Dumi's homosexuality is a most arresting and dramatic standout moment in the narrative. The fallout is in the main two-pronged. For starters, it utterly changed the tack of the Vimbai-Dumi relationship to the point of splitting the former's personality. Secondly, it exacted a heavy physical and psychological toll on Dumi that came to a head with the latter's exile. The disgusting twist taken by the relational bond between Vimbai and Dumi came as a real shocker of huge depth, for the inception betokened an outstanding promise. It is worthwhile to note, though, that the evolution of their relationship is a checkered one. When Vimbai makes up her mind to rent a room in the house she has inherited from her dead brother, it is in the spirit of keeping body and soul together without any other ulterior motive:

The extra money that I was going to get from him would go some way in helping me with the bills and other things that I needed around the house. It was an unnatural arrangement for a single woman to take in a male lodger, but I was freed from having to consider the feelings of my extended family. I could do what I liked and I didn't have to care for my reputation either, because I didn't want a man in my life. Ms Independent. (64)

Indeed, from the get go, the idea of dating Dumi was a non-starter for Vimbai. The disappointingly shocking experience from her idyllic relationship with Philip Mabayo taught her a lesson. Another reading into her lukewarm attitude towards Dumi from the outset points to a dented ego subsequent to Dumi's prominent status in the salon. Vimbai's heart-felt confession that "To be dispensable is a woman's worst nightmare and I was beginning to live it" (32) captures the depth of her troubled soul. She reaches the ultimate in humiliation when Dumi somewhat leapfrogs her as manager of the salon. In spite of Mrs Khumalo's own recognition that "Vimbai has many years of experience and is very good with our clients" and that "they all know her and respect her", she gives preference to Dumi. As to the rationale behind her choice, Mrs Khumalo has a theory:

The other person is Dumisani. He has less experience but he's innovative and creative. It was a tough choice for me, and I couldn't sleep, but my decision is ... Dumisani because he has dynamism and an X-factor that I can't quite articulate. Raise your glasses. (78)

Going forward, Vimbai pretty much snaps because she feels hard done by, "My mind went blank. My hand limply raised the cup as if by some supernatural force. All my years of loyal service down the drain" (78). Little wonder she gives Dumi, the killjoy, a wide berth. Interestingly, Dumi is cast in the mould of those folks who cannot brook the sight of a fellow being upon the rack. In a move calculated to assuage Vimbai's hurt feelings, he says with a hint of commiseration, "I just think that you worked at the salon for much longer than any of us and if I were you I would feel some sort of entitlement when this post came up" (82). The gruffness of Vimbai's comeback to these soothing words makes Dumi take the plunge and offers to quit his gig as a token of his friendship to Vimbai, "I'll resign tomorrow then," ... "Our friendship 
means more to me than some stupid job" (82). She did a double take with the mention of the word "friendship" which, from her vantage point, rings hollow. Hence, her bafflement as to why Dumi is "willing to make this sacrifice for [her] happiness." Notwithstanding, she successfully attempts to nip in the bud Dumi's resigning urge, as it were, with a sop, "I think you'll be a great manager" (82). Arguably, Vimbai goes to great lengths to mitigate the burdensome disappointment in Dumi upstaging her in the salon by resorting to what the primer of psychoanalysis Freud calls "palliative measures"2, aka "auxiliary construction". Love is the "power deflection" that she falls back on. As regards Dumi, he also has his own fair share of life's blows. Accordingly, he, after the fashion of Vimbai, makes use of palliative measures to allay his psychological pains. Vimbai is justified in spurning Dumi's friendship even through "friendship is not only an indispensable but also a beautiful or a noble thing" (Aristotle 257). In Aristotle's estimation, the genuineness of friendship that "requires long and familiar intercourse", is, to be sure, tied to mutual love. Friendship cannot obtain in a matrix of asymmetrical love:

(...) it is impossible for people to know one another till they have consumed the requisite quantity of salt together. Nor can they accept one another as friends, or be friends till each show and approve himself to the other as worthy to be loved. Those who quickly come to treat one another like friends may wish to be friends but are not really friends, unless they not only are lovable, but know each other to be so. (258)

Dumi's friendship to Vimbai is one of sorts since, from an Aristotelian vantage point, "The friendship, whose motive is utility seems, more than any other kind, to be a union of opposites, as of rich and poor, ignorant and learned. . ." Actually, Vimbai and Dumi are worlds apart in terms of family background and personal future prospects. Nevertheless, they have a commonality that bears underscoring: both of them are for different reasons estranged from their respective families. The former's fallout from her family is an offshoot from inheriting a house legally bequeathed to her by her late brother Robert, who passed away in London as a migrant worker. Even though the family left no stone unturned to disregard lock, stock and barrel Robert's will, Vimbai was able to carry the day thanks to the services of a renowned lawyer. Her adamant refusal to cave in to the steadfastness of her own blood and flesh, not the least of whom are the hardline bunch of brothers -Takesure and Knowledge- to disinherit her, reaches its acme when she remains impervious to the said brothers' threats, and her parents' agreement "that the house should go to them" (31-2)). Plainly, the shameful failure of the family to prevail upon her is doubtless a monument to female-driven assertiveness and wholesome pushback on the strictures of patriarchy: "I endured endless threats, which only stopped when I won a peace order barring my family from being a hundred metres (sic) near me or my house" (32). As to the grounds for Dumi's spat with his family, the reader are kept dangling pretty much until the end of the novel. Even so, three or four narrative pointers indicating Dumi's homosexuality can be noticed. For one thing, much to her astonishment, Dumi embraces a female-oriented job: hairdressing (65). Secondly, Vimbai's bafflement that Dumi has never "made a pass at any of the girls at work or anywhere else at that" (83). Thirdly, Dumi's steadfast unwillingness to have extra marital intercourse in spite of having on a silver

\footnotetext{
2 In Civilization and Its Discontents, Freud speaks of the travails of life that make it extremely difficult for man to cope. "Life" he says, "brings too many pains, disappointments and impossible tasks." In order to successfully bear the ordeals of life, the prime mover of Psychoanalysis says that man cannot go without what he calls "palliative measures" which can be broken down into three kinds: "powerful deflections, which cause us to make light of our misery; substitutive satisfactions which diminish it; and intoxicating substances which make us sensitive to it" (22). Substitutive substances are offered by art, which accounts for their illusory nature. Still Freud is at pains to underline that they "are psychically effective, thanks to the role which phantasy has assured in mental life." As regard intoxicating substances, they may not be as cost-effective as it might seem at first glance, because "they enter our body and alter its chemistry" (22).
} 
platter the opportunity of doing so (159). Understandably, Dumi's tepid reaction to Vimbai's sex-oriented attentions make her feels rejected: "When I tried to pull his pants off, he said, "Stop." She then desperately tries to get a handle on Dumi's attitude through guesswork: "Maybe he didn't find me attractive. He hadn't given me that impression. Had I moved too quickly? What if he thought I was I whore? I needed to understand why he was rejecting me." In a move meant to stop keeping her guessing he delivers a substantiation anchored in an oldschool mindset tinged with morality: "I really like you. But I think we should wait. One day we will get married and I want everything to be perfect. I've never slept with a woman. It's oldfashion I guess but it is the right way to do things" (132). At bottom, he is, from a Kantian ethical standpoint, "a mere deceptive of a human being, not a human being himself" in that he lives an "external lie" 3 (6: 430) to get off the hook. Actually, the sophisticated eighteenthcentury German thinker looks upon lying as a vice, the more so since it epitomizes "the greatest violation of a human being's duty to himself regarded as a moral being" (6: 429). The fact of making a declaration to someone that one knows contains "intentional untruth" is tantamount to crass betrayal of the humanity in one's own person. Kant likens a liar to less than a thing. His elaboration thereon reads as follows, "For a thing, because it is real and given, has the property of being serviceable so that another can put to some good use" (6: 629). Lying is a by-word for hypocrisy that feeds on lack of moral compass.

The tack of the argument here is that Dumi uses Vimbai as a palliative measure to get to grips with the psychological issues facing him. If anything, she is nothing but a front, a smokescreen to conceal his gayness and, more significantly, to mend fences with his family. Conversely, Vimbai comes short because of her naivety and incautiousness that have marred her calculus. Little wonder that her brutal discovery of Dumi's homosexuality was a shock to the system. After a lot of soul-searching as to Dumi's shifty attitude of late, Vimbai plays the busybody and walks into his room while he is away. Her frantic effort wrapped up paying off even though, at one point, she teetered on the brink of relinquishing after a long drawn-out fruitless search (160). Indeed, the moment she came upon "a small black journal with 'Dumisani Ncube' written in silver lettering on the sleeve" Vimbai felt relieved: "I knew I had found what I was looking for" (160). She opened the diary and -horror of horrors- was utterly disgusted by what she saw as "the contents were worse than anything [she] could ever have imagined" (163). The reality of Dumi's homosexuality had just hit home. Going forward, she averts her eyes from the diary because its contents makes her puke. To register her dashed hope, she embarks upon a scathing onslaught on the unnaturalness and immorality of homosexuality. Much as she has a lot of beef about Mugabe's misrule, Vimbai plainly admits that she sees eye to eye with the president as to his perception of the gay people, also called locally Ngochani:

My daughter had been the product of the union between man and woman. What could a man and man ever hope to produce in a million years? Even the president has called them worse than pigs - I might have disagreed with a lot of what he has done to the country but I had to agree with him there. (167)

Hints at the pathological feature of homosexuality shine through the foregoing. The brainchild of classical Psychoanalysis Sigmund Freud attempted to get at the bottom of same-sex attractions. His views on the psychical etiology of homosexuality are so thick and sometimes ambiguous, nay contradictory that it will be a tall order trying to deal with them all within the

\footnotetext{
3 In The Metaphysics of Morals, Immanuel Kant distinguishes between "internal lie" and "external lie". According to this uber-great thinker, "By an external lie a human being makes himself an object of moral contempt in the eyes of the others; whereas "by an internal he does what is still worse: he makes himself contemptible in his own eyes and violate the dignity of humanity in his own person" (6: 429).
} 
scope of this paper. Some of his reflections are so insightful into the homo condition that they bear discussing, though. Freud traces the origins of homosexuality in a psycho-social development during childhood that went awry; he labels "contrary sexuals or inverts" 4 those for whom the choice of the sexual object is for the person of the same sex. The Freudian construction of the practice of same sex activity as a deviation from "civilized" sexuality gives us a better sense of its specificities. Actually, Freud emphasizes that the psychic inability of the homosexual to relinquish his love-object, be it ever so unnatural, makes it next to impossible to comply with the moral demands of civilization The pleasure principle, in Freud's estimation, drives the activity of homosexuality. As a result, it is not commensurate with the mystique of procreation: "The common characteristics of all perversions, on the other hand, is that they have abandoned reproduction as their aim" (277). The homosexual foregrounds pleasure in his loveobject choice and that, doubtless, factors into his unwitting blindness to the realization that "the turning point in the development of sexual life lies in its subjugation to the purpose of reproduction" (Freud 277). Notwithstanding, Freud adamantly registers his rejection of the social stigma and intolerance that gay people are often at the receiving end of:

It is one of the obvious injustices of social life that the standard of culture should demand the same behavior in sexual life from everyone - a course of conduct which, thanks to his nature, one person can attain without effort, whereas it imposes on another the severest mental sacrifices though; the injustice is ordinarily nullified by disregard of the command of morality. (Freud 20)

Arguably, Freud here vindicates Michelle, Dumi's sister. In a one-on-one with Vimbai that comes in shadow of the discovery of Dumi's gayness, Michelle takes pains to get her to never ditch Dumi as she is a tower of strength to him. Additionally, part of Michelle's spiel carries an encapsulation of the intolerance-generated woes that the likes of Dumi go through at the hands of their own society:

I have known for a while that my brother is gay, and I'm cool with it. The rest of the family isn't... It was a tough time for Dumi, he has suffered a lot just for being who he is. I want you to know one thing though, Dumi loves you and chiwoniso more than anything in the world. You guys were family to him, when he had none. He is just different, in a world which wants to force him to be what he is not. Don't ever stop loving him, he needs you, more than ever. (186-7)

More's the pity, Dumi lives in a society that does not suffer gays gladly, and where anything that is akin to "Satanic behavior", as Vimbai angrily brands "homosexuality", is stamped with the utmost ferocity. Dumi's savage attack by unknown thugs and subsequent ditching along a busy road adds to the ordeals speaks volumes about being gay in Zimbabwe and, by extension, across Africa. Dumi's life-threatening injuries need urgently medical attention. However, the effects of bad governance make it hard for him to be admitted to hospital swiftly (181). Trina, a friend of Vimbai's, explains the offhandedness they are met with at hospital: "He was drifting in and out of consciousness, but they wouldn't treat him unless they had money up front." Twisting the knife in the wound, she points out with a hint of disbelief and anger:

\footnotetext{
${ }^{4}$ According to his classification, inverts can be of three kinds: absolute inverts, which means that "their sexual object must always be of the same sex, while the opposite sex can never be to them an object of sexual longing, but leaves them indifferent or may even evoke sexual repugnance"; "amphigenic inverts (psychosexually hermaphroditic)." In other words, "their sexual object may belong indifferently to either the same or to the other sex; and, occasionally inverts, namely that "under certain external conditions, chief among which is the inaccessibility of normal sexual object and imitation, they are able to take as the sexual object a person of the same sex and thus finds sexual gratification" (Three Contributions to the Theory of Sex 2). Homosexuals doubtless fit into the first category.
} 
No need to stress just now. I told them to treat him and I would get the money but they refused to do anything until I coughed up. Can you believe it? He was dying and they wouldn't touch him until they got cold cash there and then. I had to get Derek to rush in, in the middle of the night, with a suitcase full of money. (180)

Torn between her disappointment in Dumi's homosexuality and her love as well as her gratitude to his parents for giving her a new lease on life, Vimbai is prey to a lot of hesitation as to the attitude to adopt respecting Dumi. She grows to let her heart rule her head, and goes to hospital to visit Dumi. She displays the solidity of her moral compass and wisdom in the reasoning behind her decision not to have a grudge against Dumi:

"I have to say. There is no way I'm leaving his side." It's difficult to stop loving someone, even when they have done something that you once thought unforgivable. There isn't an on off switch for love I wept for Dumi and hoped that everything would turn out okay.... It would be a lie to say I did not want him to myself, but this didn't mean that if I couldn't have him, I would want him dead. Dumi was too nice a person and he'd helped me so much in my life. (182)

The hostility coupled with urge of revenge that oftentimes comes from a harrowing experience of betrayal and disappointment in a loving or friendly relationship plays second fiddle to the moral imperative of forgiveness and sympathy, in Vimbai's case. Arguably, from a psychoanalytic viewpoint, Vimbai subsumed the entirety of ego in her love-object. Indeed, in Freud's books, this goes with the territory of the process of being in love: "(...) the ego becomes more and more unassuming and modest, and the object more and more sublime and precious, until at last it gets possession of the entire self-love of the ego, whose self-sacrifice thus follows as a natural consequence" (112). She then has to swallow her pride in order to cope with "Traits of humility, of the limitation of narcissism, and of self-injury [that] occur in every case of being in love" (112). At Dumi's hospital beside, Vimbai humbly beats her chest for her responsibility for what happens to him. Dumi is possessed of an outstanding sense of humility and selfpossession that admits of no finger pointing, though. If anything, rather than pardoning, he asks to be pardoned owing to his failure to level with Vimbai from the outset. With words tinged with a guilty conscience, Dumi bares his soul to Vimbai:

"It's I who must beg your forgiveness. I should have been upfront with my true intentions for you. There were signals I gave off which misled you. You see, for a long time I used to think of my gayness as a cancer for which I needed treatment. Then I met Colin and he told me how wrong I was. Now, I realize it is just something I was born with and as long as Zimbabwe can't accept it, I'd rather live somewhere else. "I shouldn't have read your journal in the first place."

"That was meant to be. I wrote it hoping that one day someone like you might read it as an explanation of why things are the way they are. You just found it before it was ready and I was ready. (184)

This moving sort of coming out does not leave Vimbai cold. Anything but. In an endeavour to salve her conscience, Vimbai embarks upon a frantic process to help Dumi shake the dust of Zimbabwe off his feet, a country that regards him as a social misfit for just being different. She goes to see Minister $\mathrm{M}$ - a regular at the salon and whose husband counts amongst Dumi's lovers. It is not clear from the narrative how Dumi's passport wrapped up with Minister MReading between the lines, it is, nevertheless, safe to bet that the passport disappeared after men claiming to be from the CIO "came here [Vimbai's house] this afternoon and took all the things in Dumi's bedroom" (179). Minister M- has every reason to somewhat load the dice against Dumi, the more so since, upon being informed by Vimbai about the compromising contents of Dumi's diary to her husband, she talks her into entrusting the diary with her. She 
sees to it that Vimbai does not blow the lid off this unsavory business which, if brought to light, could sound the death knell for her presidential designs:

(...) I have ambitions to run to the highest office in the land. My ministry is one of the few functional ones left, because I can get things done. I've bled for this country and dedicate (sic) my life to its service. I also have many enemies all around waiting to bring me down at a moment's notice. The information that you have given would be very useful to them if it falls in their hands. (172)

When she is bullish that Vimbai's lips are sealed Minister M-'s fulfils her part of the deal as she throws "the passport at [her]" (187). Still she delivers a strong caveat to Vimbai: “'... Consider us square now. My debt to you is paid in full. When you go to sleep every night remember the consequences of what you have agreed to" (187). Vimbai, indeed, accepts to "put [her] own life down as an indemnity" so that Dumi "can leave the country" (187). Vimbai sees Dumi off to the airport. In the beginning, Dumi gave her calls regularly to hear from her, but as time went by the calls came "with less frequency". Notwithstanding, Vimbai genuinely acknowledges that her memory of Dumi will always stick with her in recognition of the goodness that he epitomizes- a cardinal quality which is thin on the ground nowadays: "In a way I will always love Dumi. He restored my faith that there are still good men out there. I never got to tell him of my deal with the minister because wherever he may be I want him to his life to the fullest, without fear" (189). Vimbai is, in many regards, instrumental in Dumi's forced exile. Nonetheless, she redeems herself by enabling him to lead overseas the kind of life that he wants, without let or hindrance.

In the final analysis, suffice to say that The Hairdresser of Harare is a reproach to modern-day Zimbabwe in many regards. The pervasiveness of the scams through the grassroots attempt to get by is measure of moral decline as well a paucity of job opportunities, which is a direct offshoot of decades of bad governance.

The author strikes a downbeat note as regards the future of his country that finds expression in the depiction of the astounding scope of top-down corrupt practices and the eye-wateringly high number of young people leaving the country in search of a better life overseas. Amongst the social woes that eat into the fabric of Zimbabwean society homosexuality features. Even though gays stray from the straight and narrow in terms of the country's traditional and moral values, Tendai Huchu does not condone his fellow-citizens' perception of them as a bad lot that should be relentlessly and mercilessly cracked down on. Vimbi shows that it is within the realm of human agency to make the world through an unreserved espousal of otherness, sympathy and love. Hopefully, Mugabe's resignation after thirty-seven years in power will herald a new era in Zimbabwe free from social and political injustice.

\section{WORKS CITED}

Akhtar, Salman. A Comprehensive Dictionary of Psychoanalysis. London: Karmac, 2009. Print.

Hazlitt, Henry. The Foundations of Morality [1964]. New York: The Foundations for Economic Education, INC., 1994. Print.

Aristotle. The Nichomachean Ethics. Trans. F. H. Peters. London: Kegan Paul, Trench, Trübner \& CO., Ltd, 1906 (tenth edition). Print.

Camus, Albert. The Myth of Sisyphus and Other Essays [1942]. Trans. Justin O’Brien. New York: Vintage, 1955. Print.

Carmichael, David L., Brian Reeves, and Audhild Schanche, eds. Sacred Sites, Sacred Places. New York: Routledge, 1994.

Elias, Norbert. The Loneliness of Dying. Trans. Edmund Jephcott. New York and London: Continnum, 2001. Print. 
Fanon, Frantz. The Wretched of the Earth [1963]. Trans. Richard Philcox with a Forward by Homi K. Bhaba and a Preface by Jean-Paul Sartre. New York: Grove Press, 2004. Print.

Freud, Sigmund. A General Introduction to Psychoanalysis. Trans. G. Standley Hall. New York: Boni and Liveright, 1920. Print.

- $\quad$-Civilization and Its Discontents (1930). With an Introduction by Christopher Hitchens. Trans. \& ed. James Strachey. New York: W. W. Norton \& Company, 2010. Print.

- $\quad-\quad$ Three Contributions to the Theory of Sexuality. Authorized translation by A. A. Brill with an instruction by James J. Putnam. New York: The Journal of Nervous and Mental Disease Publishing Company, 1910. Print.

- $\quad$ - "Group Psychology and the Analysis of the Ego. The Standard Edition of the Complete Psychological Works of Sigmund Freud, Vol. XVIII (1920-1922): Beyond the Pleasure Principle, Group Psychology and Other Works, 65-144. London: The Hogarth Press, 1921. Print.

Gordimer, Nadine. The Essential Gesture: Writing, Politics and Places. Ed. With an introduction by Steven Clingman. New York: Alfred A. Knoff, 1988.

Huchu, Tendai. The Hairdresser of Harare. Athens, Ohio: Ohio University Press, 2010.

Kant, Immanuel. The Metaphysics of Morals [1795]. Ed. \& trans. Mary Gregor with an introduction by Roger J. Sullivan. Cambridge: Cambridge University Press, 1996. Print.

Kierkegaard, SØREN. Fear and Trembling and Sickness Unto Death [1849]. Trans. \& with notes by Walter Lowrie with an introduction by Gordon Marino. Princeton: Princeton University Press, 2013. Print.

Nietzsche, Friedrich [1878]. Human-All-Too-Human: A Book for Free Spirits Part I. Trans. Helen Zimmern with an Introduction by J. M. Kennedy. Edinburgh: T. N. Foulis, 1910. Print.

Nora, Pierre. "Preface to English-Language Edition: From Lieux de mémoire to Realm of Memory," in Realms of Memory: Rethinking the French Past, under the Direction of Pierre Nora. Ed. Lawrence D. Kritzman. Trans. Arthur Goldhammer. New York: Columbia University Press

- $\quad$ - "General Introduction: Between Memory and History," in Realms of Memory. Print.

Raftopoulos, Brian, and Tyrone Savage, eds. Injustice and Political Reconciliation. Harare: Institute for Justice and Reconciliation, 2004. Print.

Raftopoulos, Brian, and Alois Mlambo, eds. Becoming Zimbabwe: A History from the Pre-Colonial Period to 2008. Harare: Weaver Press, 2009. Print.

Rawls, John. Theory of Justice. Cambridge, Massachusetts: The Belknap Press of Harvard University Press, 1999 (Revised edition). Print.

Schulz, Ortrun. Schopenhauer's Critique of Hope. Norderstedt, Germany: BoD-Books on Demand, 2014. Print.

Schumacher, Bernard N. A Philosophy of Human Hope: Josef Pieper and the Contemporary Debate on Hope. Trans. D. C. Schindler. New York: Fordham University Press, 2003. Print.

Shizha, Edward, and Michael T. Kariwo, eds. Education and Development in Zimbabwe: A Social, Political and Economic Analysis. Rotterdam, The Netherlands: Sense Publishers, 2011. Print. 